\title{
The Best Regime of Aristotle's Nicomachean Ethics
}

\author{
Thornton C. Lockwood, Jr.
}

Aristotle's Nicomachean Ethics is closely related to his Politics. Aristotle calls

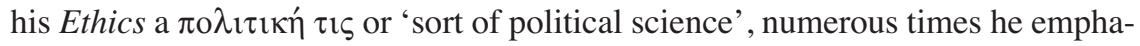
sizes the practical nature of his inquiry, and the closing pages of the Ethics are the introduction to the Politics; further, in numerous places the Ethics refers to discussions which take place in the Politics, and the Politics, in turn, explicitly refers to discussions in the Ethics. ${ }^{1}$ The two works taken together are a diptych or greater whole composed of two parts. And yet, the fit between the two works is not always smooth and sometimes it is unclear. Although both the Politics and the Ethics raise the question of what is the best regime or constitution ( $\dot{\eta} \alpha \rho i \sigma \tau \eta$ $\pi \mathrm{o} \lambda \imath \tau \varepsilon i \alpha)$ in numerous places, it is difficult to determine the identity of the best regime in the Politics. Although EN viii 10 explicitly endorses kingship ( $\left.\beta \alpha \sigma \imath \lambda \varepsilon^{\prime} \alpha\right)$ as the best regime, many commentators agree with Richard Kraut's claim that 'unfortunately Aristotle does not explicitly say why, here or elsewhere'. ${ }^{2}$ Trying to reconcile what Aristotle says about the best regime in both the Ethics and Politics simply complicates matters further.

Much work has been done on the question of what is the best regime in Aristotle's Politics, but the same question has received much less scrutiny in the case of the Ethics. ${ }^{3}$ Although the Ethics is a kind of political science, for the most part it ignores political regimes or constitutions to keep its applicability as wide as possible. ${ }^{4}$ Nonetheless, in $E N$ viii 10 Aristotle claims that kingship is the best regime, and elsewhere in the Ethics he makes remarks about regimes which yield

\footnotetext{
${ }^{1}$ For citations that allude to the unified nature of the Ethics and Politics - whether conceptually or through textual cross-references - see EN 1094b11-12, 1095a3-4, 1095b5-7, 1102a8-27, 1103b225, 1109b34-35, 1141b23-24, 1155a23-25, 1181b13-16, Pol. 1261a31, 1280a18, 1282b19, 1295a36, 1332a8, a21. See further Bodéüs 1993 and Vander Waerdt 1985a and 1991. My own translations of the Greek are based on Bywater 1894 and Ross 1957, although I am much indebted to Irwin 1999 and Rackham 1932.

${ }^{2}$ Kraut 2002, 425; cf. Miller 1995, 153n27. A prominent commentary tradition on EN viii 10 found in Ramsauer 1878, Grant 1885, ii 269-270, and Stewart 1892, ii 306, dismisses the discussion of regimes in the Ethics as an early work which Aristotle revised in the Politics. See further Gauthier and Jolif 1970, ii 699.

${ }^{3}$ For recent discussions of the notion of the best regime in the Politics, see Alexander 2000, Bartlett 1994 and 1995, Bates 2003, Chuska 2000, and Huxley 1985.

4 Vander Waerdt 1985a, 82 puts the point well: 'In presenting his teaching on political science, Aristotle must avoid making his account of the individual's moral education dependent upon the ends and educational program of any particular regime, in order to take into account the variety of regimes in which education takes place' (see also Vander Waerdt 1991, 236).
} 
coherent arguments for the claim that kingship is best. ${ }^{5}$ In order to clarify why kingship is the best regime of the Ethics, I first examine Aristotle's discussion in $E N$ viii 10. In part two I look at passages in the Ethics in which Aristotle distinguishes good and bad regimes and examine the criteria on which he bases the distinction. In the third part I argue that Aristotle's use of kingship as a model for the ordering of the soul supports and elucidates his claim that kingship is best. In $E N$ v 7, Aristotle claims that there is 'one regime which is best everywhere according to nature' (1135a5); since the regime described in $\mathrm{v} 7$ has been interpreted as involving direct civic participation, this passage appears to go against my thesis. In the fourth part I show why such an interpretation is mistaken and that, properly understood, EN v 7 in fact supports my claim that kingship is the best regime of the Ethics. In the conclusion I consider the paradox: if humans are perfected through political participation, then how can a regime like kingshipwhich denies direct civic participation to its subjects - nonetheless be Aristotle's best regime?

\section{The Ranking of Constitutions in $E N$ viii 10}

Ranking constitutions requires both a way to distinguish different kinds of constitution and criteria by means of which to rank them. ${ }^{6}$ Both Politics iii 7 and EN viii 10 divide regimes into six types: there are three 'correct' constitutions (o $\rho \theta \alpha i$ $\pi \mathrm{o} \lambda \imath \tau \varepsilon i \alpha \imath)$, namely, kingship, aristocracy, and polity or timocracy, ${ }^{7}$ and there are three regimes which are 'deviations' ( $\pi \alpha \rho \varepsilon \kappa \beta \alpha ́ \alpha \varepsilon \imath \varsigma)$, namely, tyranny, oligarchy, and democracy. ${ }^{8}$ The Politics and Ethics also agree that correct constitutions are ruled in the interest of the ruled whereas deviant regimes are ruled in the interest of the rulers. ${ }^{9}$

${ }^{5}$ EN 1160a31-37; cf. Pol. 1279a26-39. There is very little literature on the nature of kingship in the Ethics. For analysis of kingship in the Politics, see: Bates 1997, Carlier 1993, Kelsen 1937, Miller 1998, Nagle 2000, Newell 1991, and Vander Waerdt 1985b.

6 Aristotle's predecessors such as Herodotus, Plato, and Isocrates provided different ways to divide constitutions, and there was significant disagreement over whether all regimes could be reduced to two types (oligarchy and democracy), three types (monarchy, oligarchy and democracy), or, with the addition of tyranny, aristocracy, and polity, possibly four, five, or even six types. See Herodotus, Histories iii 80-82; Isocrates, Panathenaicus 132; Plato, Statesman 301a-303b, Republic 544b-d, Laws 712b8-715e; cf. Rhet. 1365b33-1366a3, Pol. 1290a12-29, 1293a35-b2. See further, Newman 1887, i 203-220; DeRomilly 1959, Fortenbaugh 1991, and Rowe 2000.

7 The Ethics, unlike the Politics, calls a regime ruled by the many towards the common good 'timocracy' based on the fact that it has a property qualification ( $\tau$ í $\mu \eta \alpha, E N 1160 b 18-20$; cf. Rep. 545b). For possible historical reasons behind Aristotle's terminological change, see DeRomilly 1959, 92-95. Ron Polansky has suggested to me that the Politics calls it 'polity' since it is really the best regime, i.e., the real $\pi \mathrm{o} \lambda \iota \tau \varepsilon i \alpha$. Throughout I will use the term timocracy rather than polity.

${ }^{8}$ EN 1160a31-37, Pol. 1279a26-39; cf. EN 1131a28-29, EE 1241b27-33. In the Rhetoric Aristotle claims that there are only four types of regimes (one of which, monarchy, admits of two species), and in the Politics one can find passages which discuss two-fold and five-fold divisions (Rhet. 1365b33-1366a3, Pol. 1290a12-29, 1293a35-b2).

${ }^{9}$ In the Politics, initially Aristotle differentiates regimes by quantitative criteria, viz., whether one, few, or many rule; his subsequent analysis points out that the regimes are in fact differentiated by 
The question of ranking regimes in the Politics is complicated because Aristotle seems to identify a number of different regimes as 'best' without clearly interrelating them. ${ }^{10}$ Nonetheless, $E N$ viii 10 -where Aristotle examines the analogies between constitutions and relations in the family-states that kingship is best overall, tyranny is worst overall, and democracy is the least bad of the deviant regimes. ${ }^{11}$ Aristotle supports ranking kingship as best with two explicit arguments, both of which turn on the juxtaposition of tyranny and kingship as being opposites ( $\dot{\varepsilon} v \alpha v \tau i ́ \alpha)$ on an evaluative scale. Aristotle's first argument asserts that whereas a tyrant looks to his own advantage in ruling, because a royal ruler $\left(\beta \alpha \sigma i \lambda \varepsilon v \delta_{\varsigma}\right)$ is independent and lacks nothing he can look to the advantage of those who are ruled (1160b2-6). ${ }^{12}$ Earlier, in $E N$ viii 9, within a slightly different context, Aristotle claimed that justice consists in the 'common good' ( $\tau$ ò

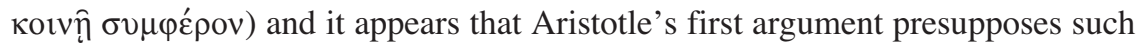
a doctrine, much like the differentiation of correct and deviant regimes in the Politics (EN 1160a11-14; cf. Pol 1279a18-20, 1279a28-29). Certainly such an argument allows one to rank kingship over tyranny, but it does not appear to justify ranking kingship as superior to aristocracy and timocracy.

Aristotle's second argument appears to be intended to do such work. After asserting that kingship and tyranny are opposites because one seeks the good of the ruled whereas the other seeks the good of the ruler, Aristotle goes on to conclude 'the superior badness ( $\chi \varepsilon i p i ́ \sigma \tau \eta)$ of tyranny among the other constitutions

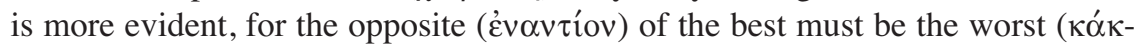

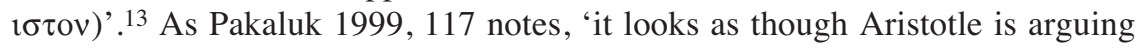
that kingship and tyranny are "contrary extremes," in the precise sense of "members of the same kind which differ the most"'. Such an interpretation is supported by the immediate sequel in the text, where Aristotle specifies a scheme of consti-

qualitative criteria, viz., whether the rich or poor rule, i.e., the different sorts of ends (Pol. 1279a2832, 1279b35-1280a7). The Ethics does not pursue the question beyond asserting the six-fold division.

${ }^{10}$ Politics iii and iv present the following possible candidates: Kingship ( $\left.\beta \alpha \sigma i \lambda \varepsilon i \alpha\right)$, which is the most fitting or just in certain circumstances (discussed in Pol. iii 14-17; Unmixed aristocracy, or the best regime given the fulfillment of one's prayers, in which the good man and good citizen are one (discussed in Pol. vii-viii); The middle regime, in which the middle class outnumbers the rich and poor (discussed in Pol. iv 11); The 'mixed' timocracy and aristocracy, or rule according to 'relative' virtue (discussed in Pol. iv 7-9); and the most common regimes-oligarchy and democracy - which although both 'deviant' species of regimes, nonetheless contain internal rankings of higher and lower subspecies (discussed in Pol. iv 3-6 and vi). See further Pol. 1288a33-38, 1289a38-b11, 1296b3-13, 1288b22-38; cf. 1276b36-38, 1284a2-4, 1284b26.

${ }^{11}$ EN 1160a36-37, 1160b7-10, b20-23; cf. 1161b31-33, 1161b7-11. Although the Eudemian Ethics does not endorse one regime as best, it does apparently endorse the claim that the aristocratic association is best (EE 1241b35-38). For an explanation of the textual difficulties related to the passage, see Donini 1999, 153, 218. More generally, see Pakaluk 1998, 425.

12 On the notion that $\varepsilon \dot{\varepsilon} \rho \gamma \varepsilon \sigma i \alpha$ is a king's proper virtue in Aristotle and other contemporary authors, see Vander Waerdt 1985b, 264-265 n23.

13 1160b7-9. Scholars have been puzzled about whether this argument implies that the goodness of kingship is made evident from the overwhelming badness of tyranny or vice versa. Regardless of which version is endorsed, the argument still endorses the claim that kingship is best based on the argument from opposites. For analysis of the problem, see Gauthier and Jolif 1970, ii 701. 
tutional change ( $\left.\mu \varepsilon \tau \alpha \beta \beta_{\lambda} \eta \dot{n}\right)$ which asserts that changes within kinds of opposites (e.g., kingship to tyranny, aristocracy to oligarchy, and timocracy to democracy) are most common because they involve the least amount of change. ${ }^{14}$ Indeed, the remainder of Aristotle's discussion of cities and households is concerned with the juxtaposition of opposites rather than making comparisons between different correct or deviant regimes (although compare 1161b9-11).

In sum, Aristotle's discussion of constitutional regimes and households in EN viii 10 supports the following claims. First, the Ethics, like the Politics, articulates a six-fold division of regimes which separates different good and bad regimes. Second, although the identity of the best regime in the Politics is hard to determine, $E N$ viii 10 unambiguously states that kingship is the best constitution. Third, although Aristotle's ranking is based primarily on the juxtaposition of opposites that he provides, it also presupposes the criterion of the common good as a means of dividing and ranking regimes. The Ethics articulates other criteria for ranking regimes in addition to that of the common good.

\section{Criteria for the Ranking of Constitutions in the Ethics}

In $E N$ viii 10 Aristotle divides correct and deviant regimes with reference to the criterion of the common good or advantage of those ruled. Such a criterion appears insufficient for ranking regimes internal to the divisions of correct and deviant regimes. Although kingship is better than tyranny because it aims at the common good, Aristotle seems not to use the common good as a metric to rank, say, kingship over aristocracy or either regime over timocracy. As commentators on the Politics have long recognized, Aristotle's rankings within the classes of legitimate or right regimes must be based on a criterion beyond the common good as aim (Newman 1887, i 217-218, Barker 1959, 307-310, and Fortenbaugh 1991, 234-236). Such additional criteria are not only at play in the Politics, though; one can find evidence of them in the Nicomachean Ethics. In addition to the common good, Aristotle uses the notions of rule of law and virtue to rank different regimes.

The first criterion concerns whether a regime is one in which laws or men are sovereign. Aristotle inherits such a notion from Plato's Statesman, although Aristotle provides an apparent twist to the Platonic analysis of the question. In the Statesman, the Stranger ponders which regime is better, one in which a superior man rules or an aristocratic one in which law rules over individuals. Whereas the Statesman endorses the claim of the superior man, Aristotle in his Politics seems to side with the superiority of rule of law. ${ }^{15}$ But the discussion of rule of law in

14 1160b10-23. Aristotle devotes almost all of Politics v to the subject of constitutional change and revolution, and the analysis in viii 10 is admittedly brief and overly simplistic in comparison. See esp. Pol. v 10-12; cf. 1286b4-27, 1295b38-1296a6.

15 Plato, Statesman 302b ff. In Politics iii 15-17 Aristotle presents the problem dialectically with points raised on both sides of the question of whether a man or the law should rule. He appears to side with the rule of law, although it is precisely the problem of the 'king over all' ( $\pi \alpha \mu \beta \alpha \sigma \imath \lambda \varepsilon i ́ \alpha)$ which causes confusion over Aristotle's final answer to the question. See further Pol. 1287a23-33, 1288a25- 
the Ethics goes in a different direction, namely, to the concept of virtue. Whereas the notion of rule of law in the Politics champions the impartiality of law over the human passions and self interest, in the Ethics rule of law is connected to the common good and supreme virtue. ${ }^{16}$

In Ethics v 6, Aristotle articulates the concept of rule of law in his discussion of political justice. Political justice exists only between free and equal individuals living within a political society under the rule of law because it is law which distinguishes justice and injustice (1134a26-34; see further Lockwood 2006). In the sequel, he goes on to state that 'this is why we do not permit a man to rule, but the law, because a man rules in his own interest, and becomes a tyrant; but the ruler is a guardian of justice, and if of justice, then of equality'. ${ }^{17}$ Such remarks seem to echo the notion of law in the Politics. But earlier, in his account of 'complete justice' or the whole of virtue towards others, Aristotle makes use of the same notion of law and connects it to the common good. He writes:

Since, as we saw, the lawless person is unjust and the lawful person is just, it clearly follows that whatever is lawful is in some way just; for the provisions of legislative science are lawful, and we say that each of them is just. In every matter that they deal with, the laws aim either at the common benefit of all, or at the benefit of those in control, whose control rests on virtue or on some other such basis. And so in one way what we call just is whatever produces and maintains happiness and its parts for a political community. ${ }^{18}$

But, as Aristotle goes on to say, such law is correct only in the case that it requires actions in accord with virtue and prohibits action in accord with vice (EN 1137a10-13; cf. 1116a19-20, 1144a15, 1152a21-24). In other words, Aristotle links the common good to the promotion of virtue through the notion of law. But virtue is just the sort of criterion that one needs to make rankings internal to the class of correct regimes.

In the discussion of ethical virtue in the Ethics, Aristotle suggests that virtue is a criterion which specifies which regimes are more effective at bringing about

29.

${ }^{16}$ For the question of impartiality and rule of law in the Politics, see 1287a33, 1280a15-17, 1286a16-20, a34, 1287b4-5; cf. 1292a3-32, 1292b5-7, b11-22, 1292b27 ff., 1294a1-10, 1295a15-17, 1296b35-40. See further Miller 1995, 79-84.

${ }^{17}$ EN 1134a35-b2. Manuscripts and editors have differed on whether at 1134a35 one should

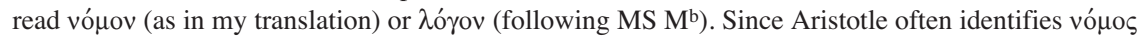
with $\lambda$ ó $\gamma \circ \varsigma$ (see, e.g., $E N$ 1180a21-24, Pol. 1286a16-18, 1287a33), the difference may not be great.

${ }^{18}$ EN 1129b11-19, Irwin 1999 follows Bywater 1894 and Jackson 1879 in rendering the Greek as it is found in the manuscript tradition. Other editors and translators, such as Stewart 1892, Gauthier and Jolif 1970, and Apostle 1984 have proposed emendations to the text on the presupposition that the passage is intended to map onto the discussion of the common good in Pol. iii 7.1279a29-31, although the terminology is slightly different. Although the passage is related to the division of regimes in Politics iii 7, I follow Irwin because I do not believe that the argument requires Aristotle to reproduce that division of regimes within this context. 
the common good. The goal of political science is the highest good, but the inculcation of virtue amongst one's citizens is the key instrument for obtaining that goal (EN 1094a27-94b12). In Aristotle's words, 'we have stated that the supreme Good was the end of political science, but the principal care of this science is to produce a certain character in the citizens, namely to make them virtuous and capable of performing noble actions' (1099b29-1100a2; cf. 1102a5-16, 1152b14). Since political scientists and regimes can be judged insofar as they obtain that end, the regime best at inculcating virtue is the best regime. Aristotle puts the point most explicitly in his discussion of the inculcation of ethical virtue.

We become just by doing just acts, temperate by doing temperate acts, brave by doing brave acts. This truth is attested by the experience of cities: lawgivers make the citizens good by training them in habits of right actions. This is the wish of every legislator; if he fails to do it well he misses his goal. Correct habituation distinguishes a good regime ( $\pi \mathrm{o} \lambda \iota \tau \varepsilon i \alpha \alpha \dot{\alpha} \gamma \alpha \theta \dot{n})$ from a bad one. (1103a34-b6)

Aristotle links the goodness of a regime to its stance towards virtue. Such a criterion is not an alternative to the common good, but it allows for rankings within the class of right regimes, since although kingship, aristocracy, and timocracy all aim at the common good, they have different levels of virtue within their societies. Within the Politics, Aristotle makes clear that the closest timocracy can come to virtue is a sort of martial virtue broadly available to all citizenry, but aristocracy, with education and resources, can aspire to a higher level of virtue (1283a19-23, 1288a6-15, 1291a21-28, 1295a25-36). Nothing Aristotle says about education or civic involvement in the Nicomachean Ethics undermines such theses from the Politics. But what is peculiar is that since the Ethics presents kingship as a superior model of ethical inculcation, it appears to elevate kingship above aristocracy and timocracy on the basis of the criterion of virtue.

\section{Kingship as a Model in the Ethics}

At several places in the Ethics, Aristotle provides kingship as a superior model for the inculcation of ethical virtue. Of course, because kingship provides a superior model for ethical inculcation at various stages of one's life, it does not follow that kingship is the best regime. Being a model for virtue is not the same thing as being a criterion to rank regimes..$^{19}$ Nonetheless, Aristotle's use of the model of kingship helps explain the claim that kingship is the best regime. Thus, the fact that Aristotle uses kingship as a superior model for virtue in the soul sheds light on one reason kingship is superior to other regimes as far as the Ethics is concerned.

Aristotle uses the model of kingship in two separate but interrelated ways in the Ethics. On the one hand, when Aristotle discusses the relationship of the

${ }^{19}$ I am especially grateful to Ron Polansky for making this point clear in his comments on my article. 
rational and irrational parts of the soul in his moral psychology, he argues that kingship provides a model for how an individual should organize reason, spirit, and appetite. On the other hand, when Aristotle addresses the problem of ethical education at places in the Ethics, he argues that the regime of kingship provides superior training of individuals because of the force of command of a truly virtuous king. Since Aristotle believed that different governments inculcate their own ethical world views, it is reasonable to connect these two models by arguing that a kingly regime best inculcates a model of the soul in which reason rules like a king (Pol 1260b8-13, 1289a15-18, 1295a40).

Aristotle believes that the relationship between a king and subject is fundamentally similar to the relationship between a father and son. At several places in the Ethics, Aristotle uses the king/subject or father/son relationship as a model for the relationship of reason, spirit, and appetite. Thus, Aristotle claims that one part of the irrational part of the soul, namely,

the appetitive part ( $\dot{\pi} \pi \theta 0 \mu$ o $1 \kappa o ́ v)$ and the desiring part in gen-

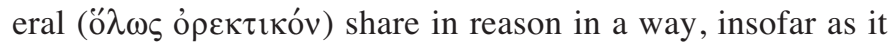
both listens to reason and obeys it. This is the way in which we are said to 'listen to reason' from fathers or friends, as opposed to the way in mathematics. ${ }^{20}$

Aristotle uses a similar metaphor in his explanation of why akrasia caused by

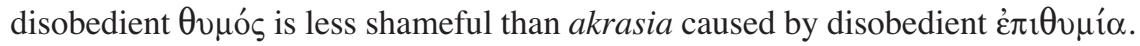
In the first kind of akrasia disobedient $\theta v \mu$ ó $\varsigma$ can hear something of reason

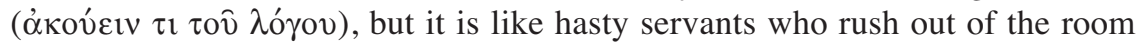
without understanding an order or watch dogs who bark at every noise before knowing its source; in the second kind of akrasia disobedient $\dot{\varepsilon} \pi \imath v \mu \mu_{1} \alpha$ rushes to its source of pleasure without listening at all (1149a25-30, a35-37). Aristotle's example, adapted from Plato's Republic, views $\theta v \mu$ ó $s$ as a part of the soul capable of obedience to reason just like the appetitive part of the soul. ${ }^{21}$

In his discussion of deliberation and choice, Aristotle uses the model of the

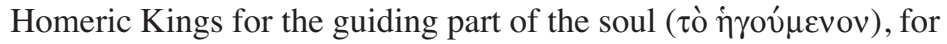

each of us stops inquiring how to act as soon as he traces the principle to himself, and within himself to the guiding part; for this is the part that decides. This is also clear from the ancient political systems described by Homer; there the kings would first decide and then announce a decision to the people. (1113a5-9; cf. 1151a20-26, 1178a2-4, 1177a14-18)

By contrast, Aristotle uses the model of a city which has enacted but does not obey its good laws to illustrate the nature of the akratic or unrestrained man; the

${ }^{20}$ EN 1102b29-33; cf. 1138b7-15; 1166b19-23, Pol. 1254b3-10, 1260a5-14. At Rhet. 1417a1921, as a referee for Ancient Philosophy has pointed out, Aristotle distinguishes mathematical treatises

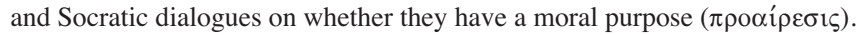

${ }^{21}$ See Republic 375c-e, 403e, 410c-d, 485a, 486c, 503b-c; cf. Pol. 1264b9. For other examples of the metaphor of 'listening to reason' in Aristotle, see EN 1095b10-13, 1105b12-17, 1117a5-9, 1119b11-16, 1139a26, 1169a15-18, 1179b27-28, 1180a10-13; Pol. 1327b30-1328a17. 


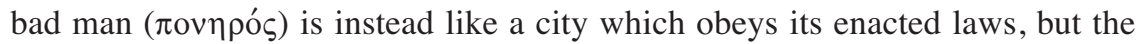
laws are bad (1152a19-25). Although Aristotle does not extend the metaphor to the nature of the $\sigma \omega \dot{\varphi} \rho \omega \mathrm{v}$ or temperate man, presumably he is one whose reason has enacted the proper laws for the desires to follow, and the desires do so obediently, like a subject obeying a king (1117b22-23, 1118a23-27, 1118b2-8).

Although these examples of the ruling part of the soul are only 'metaphors' which Aristotle uses to illuminate the proper ordering of the parts of the soul, in his discussion of ethical education in $E N \times 9$ Aristotle considers the real problem a city or family faces with respect to authority and training in virtue. In the last chapter of the Ethics, Aristotle considers the efficacy of ethical speeches ( $\lambda$ ó $\gamma o 1$ ), and somewhat pessimistically concludes that only force keeps the many in line, but for those who have been brought to love what is noble or shun what is shameful, there may be hope (1179b4-16). The problem is that learning to love what is noble is difficult and goes against what is easy and pleasant. Therefore, the question turns on whether an effective system of ethical education ought to be the responsibility of the family or the city. Although Aristotle grants that there are advantages to education within the household, he writes that

Someone who is to be good must be finely brought up and habituated, and then must live in decent practices, doing base actions neither willingly nor unwillingly. And this will be true if his life follows some sort of reason (vov̂s) and correct order that prevails on him. Now a father's instructions lack this power to prevail and compel; and so in general do the instructions of an individual man, unless he is a king or something like that. (1180a14-21)

In the sequel, it is true, Aristotle goes on to endorse a form of public ethical education which is supported by education in the family. But it appears that Aristotle makes such a point only because of the practical problem of finding kingly individuals. $^{22}$ On a practical level, it may be unrealistic to expect every regime to possess a virtuous king just like it would be unrealistic to assume that every father is a good guide for his sons or every soul places reason firmly in command over the desires. But such matters of practicality do not detract from the best model. It is best that reason rules the desires and a father rules his children like a virtuous king rules his subjects. Since kingship provides the model for virtue in the soul and the most effective means of inculcating virtue, one can see a reason why $E N$ viii 10 claims that kingship is the best regime.

The question of practicality helps deflate an objection that might be raised against my claim that kingship is the best regime of the Ethics. The Politics acknowledges the rarity of kingly regimes because of the historical changes in

22 At 1180a30-31, Aristotle favors private family education when common care is neglected in one's city, but he does not state the cause of this public neglect. I suspect it is the result of the rarity of virtuous individuals.

${ }^{23}$ As he puts it at one point, 'Royal governments do not occur any more now, but if ever monar- 
Greece and emphasizes the civic republicanism of the polis. ${ }^{23}$ But as readers of the Politics are well aware, there is a fundamental difference between the question of what is the best constitution for most people and what is the best constitution without qualification (1288b22-40, 1295a25-35, 1325b33-40). There are numerous places in the Ethics where Aristotle's discussion naturally leads one to assume that he has a sort of civic republicanism in mind as the best regime, for instance in his discussions of political courage, political charity towards the community, political justice, or political friendship (1116a17-b3, 1122b22-25, 1123a2-7, 1134a25-b17, 1167a27-b4). To claim that kingship is the best regime of Aristotle's Nicomachean Ethics does not force one to claim that the model of a civic republic is a bad regime or that political justice or political friendship are irrelevant (even if they have no place in a royal regime). Rather, both timocracy - the regime modeled on brotherhood in which people take turns ruling and being ruled and so exercise political justice (1161a4-9, 1161a25-30) - and kingship are correct forms of government, but nonetheless $E N$ viii 10 claims that kingship is the best regime, even if presumably it is a rare one.

\section{The Universal Best Regime of the Ethics}

There remains one passage which seems to be in conflict with EN viii 10's claim that kingship is the best regime. In $E N \mathrm{v} 7$, Aristotle claims that

The things that are just not by nature but according to human enactment are not everywhere the same since regimes are not the same everywhere; nonetheless, there is only one regime which is everywhere best according to nature. (1135a3-5)

Although clearly Aristotle is talking about the nature of the best regime in this passage, he neither identifies what that regime is nor is it certain that he has in mind the ranking scheme of the Politics. I wish to argue that the regime that Aristotle has in mind at $1135 \mathrm{a} 5$ is the $\pi \alpha \mu \beta \alpha \sigma 1 \lambda$ cí $\alpha$ or absolute kingship discussed in the Politics, and if I am correct, then $1135 \mathrm{a} 5$ supports my claim that kingship is the best regime of Aristotle's Nicomachean Ethics. The main problem with endorsing any regime as being 'the one best everywhere' is that Aristotle believes that different regimes are suited for different places and different kinds of peoples ( $P o l$ 1287b37-1288a5, 1281b32, 1296a19). But the regime of $\pi \alpha \mu-$ $\beta \alpha \sigma \imath \lambda$ eí $\alpha$ in which an individual's virtue is so superior that it is incomparable wherever that person resides is the exception. ${ }^{24}$ Or as Aristotle puts it in the Poli-

chies arise, they are rather tyrannies because kingship is rule over willing subjects but with sovereignty over greater matters, but men of equal quality are numerous and no one is so outstanding as to fit the magnitude and dignity of the office' (Pol. 1313a4-8); cf. 1252b19-23, 1286b10-23, 1297b24-29. For the same reason, Aristotle also points out that tyrannies are far less common in his time (1304b15-23).

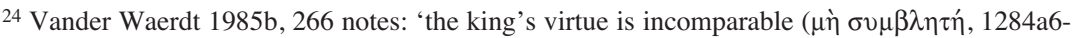
7) to that of his subjects not because it exceeds all of theirs, taken together, but because it differs in

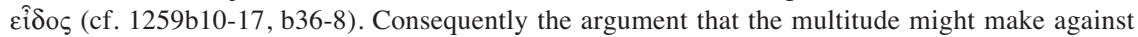
those who claim to rule on the basis of merit or wealth - that the people taken together are more vir- 
tics,

When it comes about that there is either a family or some one individual that differs from the others among him in virtue so greatly that his virtue exceeds that of all the others, then it is just for this family to be the royal family or this individual king and sovereign over all things... It is not proper to call upon him to take his turn as a subject; for it is not in the order of nature

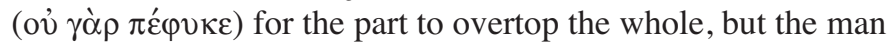
that is so exceptionally outstanding has come to overtop the whole community. Hence it only remains for the community to obey such a man, and for him to be sovereign not in turn but absolutely. ${ }^{25}$

In sum, if there is such a thing as a 'regime which is best everywhere' it must be Aristotle's $\pi \alpha \mu \beta \alpha \sigma \imath \lambda$ cí $\alpha$ or kingship over all, because the virtue of such a single individual trumps the claims of all other individual claims to rule.

My interpretation of $1135 \mathrm{a} 5$ clashes with two pre-eminent readings of the passage, and showing why my interpretation is superior helps to elucidate the passage in question. For instance, Miller 1995 has argued that the 'one best regime according to nature' is the model to which legislation in all other regimes - no matter where-ought to approximate (Kraut 2002, 130-132, espouses a similar idea). The first paragraph of Nature, Justice, and Rights reads:

Aristotle maintains that there is only one constitution which is everywhere according to nature the best ( $E N \vee 71135 \mathrm{a} 5) \ldots$ The best constitution serves as a standard by which politicians can establish, preserve, and reform different political institutions appropriate to a wide variety of social circumstances. (Miller 1995, vii; cf. 67, 75-76, 122, 127, 183-188, 191)

That one regime which most promotes human nature and allows for each and every citizen to flourish and be happy is the ideal state of Pol vii-viii, and Miller believes all other regimes should aspire to such a naturalistic ideal. ${ }^{26}$

The main problem with Miller's reading of $1135 \mathrm{a} 5$ is that it ascribes to Aristotle belief in a regulative ideal which seems foreign to the spirit of Aristotelian philosophy and contrary to the discussion of the various forms of the best regime in the Politics and Ethics. It would appear to be an axiom of Aristotelian practical

tuous or wealthy than the few or one, even if less so taken singly (1283a42-b35) - cannot apply in this case, since the king's heroic virtue, being different in عî $\delta$ os, simply is incomparable to theirs'.

${ }^{25}$ Pol. 1288a15-19, a25-29; see also 1283b20-24, 1284b26-34, 1284a3-14, 1284b25-34, 1325b10-14. Scholars have expressed doubt about the possible existence of such an individual. For instance, Mulgan 1977, 87, 88 claims that this discussion is 'purely hypothetical' and only provides a 'limiting case' to Aristotle's discussion of regimes (cf. Simpson 1998, 192 and Miller 1995, 234239).

${ }^{26}$ Indeed, Miller 1995, 252 even goes so far as to suggest that the regime described in Pol. viiviii, 'though possible in principle, was unattainable in practice on Aristotle's view', and elsewhere he describes it as merely a 'regulative ideal' (Miller 1996, 894-895).

${ }^{27}$ More precisely, the question turns on whether $\pi \alpha v \tau \alpha \chi 0 \hat{v}$ (1135a5) should be understood parti- 
philosophy that, contra the idealism which Aristotle imputes to Plato, the good is an object of practice-namely, it is a $\pi \rho \alpha \kappa \tau 1 \kappa o ́ v ~(1096 b 33-37,1095 a 16-17$; cf. Pol 1265a17-18, 1325b38-39). In EN iii 3, Aristotle points out that we deliberate about things within our control and which are attainable by action, but more specifically, attainable by our action: he writes "no Lacedaemonian deliberates

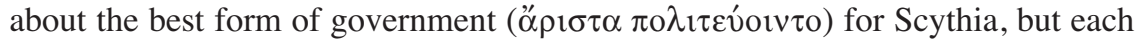
group of individuals deliberates about the actions they themselves can do' (1112a28-30). No one deliberates about regulative ideas, but about what can be done in one's own time and place. In sum, Miller's vision of an ideal state which can serve as a model for all regimes ignores the extent to which local considerations determine what is best for each place.

A second interpretation of $1135 \mathrm{a} 5$ which I wish to consider is that of Mulhern 1972, who has argued that the claim that 'there is one best regime everywhere according to nature' could be interpreted in two different senses depending on how one understands the placement of the quantifier 'everywhere' ${ }^{27}$ The first sense-similar to how Miller reads the passage - interprets Aristotle as claiming that no matter where you are, the best regime is a regulative ideal which gives guidance to the regime under which you live, because there is one regime which is best by nature everywhere. The second sense - which Mulhern endorses interprets Aristotle as claiming that in each and every place there is one and only one regime which is best for that place. In support of the latter reading, Mulhern argues that throughout the Politics, Aristotle is 'practically minded', or constantly occupied by the conditions under which his intended audience operate. But for such an audience, namely, an audience of legislators hoping to stabilize their regimes and ameliorate the most pernicious elements of faction, elevated rhetoric about a 'city on a hill' is useless.

If one understands Aristotle's best regime to be a sort of constitutional republic or aristocracy which presupposes things like leisure and rights for its citizenry, material wealth, and a certain refinement of culture and education, then Mulhern is correct to say that such a regulative ideal is irrelevant to the great majority of legislators in the world. But Aristotle's virtuous royal ruler towers above all members of his or her city - if not the world as a whole - and it would be impossible to imagine any place where such an individual would find an equal with whom to share rule. Mulhern's criticisms of a regulative ideal undermine Miller's assertion that there is a constitutional republic which can serve as a model for all legislators, but they do not undermine the claim that in extraordinary circumstances there may be someone whose virtue justifies a claim to rule wherever that individual is. In sum, not only is Aristotle's account of that 'one regime which is everywhere best according to nature' consistent with the claim that the best regime of the Ethics is kingship; it seems that the only plausible

tively rather than collectively. Although Aubenque 1980 once supported such a reading, he has more recently accepted the collective reading (see Aubenque 1998,43n14).

28 As Destrée 2000, 226-227 has pointed out, a weakness of Mulhern's own interpretation of 
interpretation of $1135 \mathrm{a} 5$ must identify the best regime under discussion with an absolute kingship based in virtue. ${ }^{28}$

\section{Conclusion: The Intended Audience of the Nicomachean Ethics}

In Nicomachean Ethics viii 10 Aristotle claims that kingship is the best regime, but at first glance he appears to present very little argumentation for that claim beyond the assertion that kingship is the opposite of tyranny. I have tried to show that such a claim derives support from other passages in the Ethics. One criterion which Aristotle mentions for ranking regimes in the Ethics, namely, the notion of virtue, supports the claim that kingship is the best regime. Further, the king/subject relationship provides a model for the transformation and ordering of the soul and helps elucidate $E N$ viii 10 . Put slightly differently, since the kingly individual is the most virtuous one, there must be a sense in which the kingly regime is best, regardless of the possibility of its implementation. My argument concedes that there is much discussion of political activity between equals in the Ethics, but that is just to acknowledge that regimes which foster civic participation can be correct regimes without necessarily also being the best regimes. Finally, I have argued that the identity of Aristotle's enigmatic discussion of a universal best regime is most plausibly construed as kingship, because only a kingship based on the absolute supremacy of an heroically virtuous man justifies that man's rule regardless of local conditions or particular circumstances. Such is my main argumentation.

Nonetheless, a paradox remains, one which has been well-posed by Vander Waerdt 1985b, 249-253. If Aristotle believes that virtue is developed through civic participation and reciprocal rule, and virtue is a criterion of the best regime, then how can the regime of kingship - which denies subjects the opportunity of political participation - ever be considered the best regime? Vander Waerdt answers his own paradox within the context of the Politics by claiming that the $\pi \alpha 1 \delta \varepsilon i \alpha$ prescribed in the Politics is a better source of ethical inculcation than civic participation, but its leisure presupposes citizens whose political problems are resolved by an absolute king. Such a generally accessible $\pi \alpha 1 \delta$ cí $\alpha$-based primarily in the musical and poetic arts rather than the contemplative sciencesprovides a way to bring virtue and happiness to the people of a regime (Vander Waerdt 1985b, 261-264; cf. Lord 1978 and 1982). Unfortunately, although Vander Waerdt's plausible suggestion works well in the case of the Politics, where Aristotle understands philosophy primarily as generally accessible $\pi \alpha 1 \delta$ cí $\alpha$, the solution will not work for the Ethics. The account of philosophy in EN x is that of theoretical contemplation accessible only to a very few sages who in a sense live outside the framework of Politics. Very few subjects living under the regime of the $\pi \alpha \mu \beta \alpha \sigma i \lambda \varepsilon i \alpha$ would be able to achieve such intellectual mastery because of

$1135 \mathrm{a} 5$ is that it seems indistinguishable from that of the Sophistical interlocutors with whom Aristotle is arguing in $E N \mathrm{v} 7.1134 \mathrm{~b} 24-27$.

${ }^{29}$ EN 1179b7-1180a18. On the question of the intended audience of the Ethics, see further Tes- 
the arduous and complex nature of such philosophizing. Perhaps a consideration of the intended audience of the Nicomachean Ethics can provide an alternative solution to the paradox of inculcating virtue without civic participation.

Although there is debate about precisely who is the intended audience of Aristotle's Nicomachean Ethics, certainly one plausible candidate is the class of those good-natured and noble-loving young men whom Aristotle claims can be effected by exhortations of virtue. ${ }^{29}$ Ethical speeches have no effect on those who have not been raised to take pleasure and pain in the right sources, and those who have already reached the pinnacle of ethical and intellectual virtue hardly need the guidance of another. And yet between those two extremes, there lies those individuals - primarily young men - whose souls are capable of listening obediently to the advice of their elders. The Hesiod which Aristotle invokes at the opening of the Ethics identifies such an audience:

He who grasps everything himself is best of all;

He is noble also who listens to one who has spoken well;

But he who neither grasps it himself nor takes to heart what he

hears from another is a useless man. ${ }^{30}$

Men of noble natures who have not yet grasped everything for themselves are old enough to have experience of the relevant matters of ethics and politics, but they still need the exhortation of a superior.

Aristotle's support for kingship as the best regime may be explainable on the basis of the rhetorical structure of the Nicomachean Ethics itself. Just like kingship provides a model for the ordering of the soul and ethical instruction, it also provides a model for the relationship between an author and his or her readers. Some works, like Platonic dialogues, seem to invite their readers to pick up loose threads in the argument so that the readers become interlocutors in Socratic dialogue. Other works, like Lucretius' De rerum natura, seek to sweeten difficult words with poetic honey, to make them more palatable. What seems stylistically distinctive about Aristotle's Nicomachean Ethics is its authoritative voice which instructs, as if, from the professor's lectern. ${ }^{31}$ But the lecturer's classroom is not a democracy in which all voices are equal and one learns through challenging the lecturer. Rather, the author of the Nicomachean Ethics speaks to its intended lis-

sitore 1996, 9-23 and Bodëús 1993, 83-122. In Lockwood unpublished, I argue that the interlocutors of Aristotle's Ethics are his contemporaries in the Academy. If that is correct, then the intended audience of the Ethics is not only noble-loving young men, but noble-loving young philosophers.

${ }^{30}$ EN 1095b10-13, Irwin 1999 trans.; cf. Works and Days, 293, 295-297. Since Aristotle introduces Hesiod's poetry with the imperative $\dot{\alpha} \kappa о v \sigma \alpha ́ \tau \omega$, it seems that he is addressing not someone who grasps things himself but rather one who listens well.

${ }^{31}$ It seems likely that the Nicomachean and Eudemian Ethics have different authorial voices and intended audiences. See further Allan 1961, 304-305 318, who suggests that the Nicomachean Ethics is related to the Eudemian Ethics like Descartes' 1641 Meditations are related to his 1644 Principles of Philosophy. See also Pakaluk 1998, who finds the Eudemian Ethics on the whole more egalitarian than the Nicomachean.

32 Owens 1978, xi claimed of Aristotle's authorial voice that 'The Stagirite is a splendid talker, 
teners like a king to his subjects. ${ }^{32}$ Because the Ethics is a practical treatise concerned with the guidance of those who are not completely virtuous, it is structured in such a fashion to speak authoritatively to its obedient auditors. The regime of kingship provides the perfect model for such a discourse, independent of any questions about politics or the establishment of different regimes in particular cities, and my thesis helps explain the authorial voice of the Nicomachean Ethics. As noted at the outset, the Ethics and the Politics are two parts of a greater whole and both are practical or directed towards action. But whereas the Politics is 'practical' with respect to the implementation of different regimes in different places, the Ethics is practical with respect to the implementation of complete virtue in its appropriate audience. As the Politics notes, the rule one exercises over free and equal men must first be learned by being ruled ( $P o l$ 1277b7-10; cf. 1332b12-27, 1333a2-3). ${ }^{33}$

Department of Philosophy

Fordham University

New York NY 10023

\section{BIBLIOGRAPHY}

Alexander, L. 2000. 'The Best Regimes of Aristotle's Politics' History of Political Theory 21: 189216.

Allan, D.J. 1961. 'Quasi-Mathematical Method in the Eudemian Ethics' 303-318 in Mansion ed. 1961.

Apostle, H.G. 1984. Aristotle's Nicomachean Ethics. Grinnell: Peripatetic Press.

Aubenque, P. 1980. 'La Loi selon Aristote' Archives de Philosophie du Droit 25: 147-157.

Aubenque, P. 1998. 'Aristote était-il communautariste?' 31-43 in Gomez and Canstro edd.1998.

Barker, E. 1959. The Political Thought of Plato and Aristotle. New York: Dover Publications.

Bartlett, R.C. 1994. 'Aristotle's Science of the Best Regime' American Political Science Review 88: 143-155.

Bartlett, R.C. 1995. 'Controversy: Aristotle's Science of the Best Regime' American Political Science Review 89: 152-160.

Bates, C. 1997. 'The Rule of Law or Pambasileia: Competing Claims for Rule in Aristotle's Politics' 195-211 in Rubin ed. 1997.

Bates, C. 2003. Aristotle's Best Regime. Baton Rouge, LA: Louisiana State University Press.

Bodéüs, R. 1993. The Political Dimension of Aristotle's Ethics. Jan Garrett trans. Albany, NY: State

but a poor listener. Just as he read in his predecessors only imperfect developments of his own doctrines, so does he continue in a like inability to see a question from a mediaeval or a modern stand. He is wrapped in his own procedure, he has no sympathetic interest in the viewpoint of any one else. He will impart an extraordinary wealth of thought, if one has the patience to listen. But if he is told what

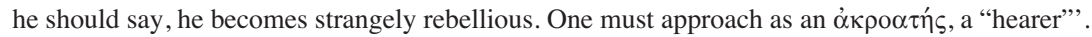

${ }^{33}$ I am grateful to Peter Simpson, J.J. Mulhern, Fred Miller, and Clifford Bates for participating on a panel on Aristotle's best regime at the 2005 Northeastern Political Science Association annual meeting which I chaired. Many of the ideas of this article grew out of debate with their excellent contributions to that panel. I am also grateful to Ron Polansky and an anonymous referee for Ancient Philosophy for their careful and detailed criticisms and their unveiled skepticism about my argument. Responding to their remarks has improved my arguments substantially, even if not sufficiently to induce their assent. 
University of New York Press.

Bywater, I. 1894. Aristotelis Ethica Nicomachea. Oxford: Clarendon.

Carlier, P. 1993. 'La notion de pambasileia dans la pensée politique d'Aristote' 103-118 in Piérart ed. 1993.

Chuska, J. 2000. Aristotle's Best Regime. Washington, DC: University Press of America.

DeRomilly, J. 1959. 'Le classement des constitions d'Hérodote à Aristote' Revue des Études Grecques 72: 81-99.

Destrée, P. 2000. 'Aristote et la question du droit naturel (Eth. Nic. V,10, 1134b18-1135a5)' Phronesis 45: 220-239.

Donini, P. 1999. Etica Eudemia. Rome: GLF Editioni Laterza.

Fortenbaugh, W.W. 1991. 'Aristotle on Prior and Posterior, Correct and Mistaken Constitutions' 226237 in Keyt and Miller edd. 1991.

Gauthier, R.A. and J.Y. Jolif. 1970. L'Ethique à Nicomaque. 2nd edn. 2 vols. Paris-Louvain: Publications Universitaires.

Gomez, A.A. and R.M. Canstro edd. 1998. En torno a Aristoteles. Univ. de Santiago de Compostella. Grant, A. 1885. The Ethics of Aristotle. 4th edn. revised. 2 vols. London: Longmans, Green \& Co.

Huxley, G. 1985. 'On Aristotle's Best State' History of Political Thought 6: 139-149.

Irwin, T.H. 1999. Nicomachean Ethics. 2nd edn. Indianapolis: Hackett Publishing Company.

Jackson, H. 1879. ПEPI $\triangle \mathrm{IKAIO \Sigma YNH \Sigma .} \mathrm{The} \mathrm{Fifth} \mathrm{Book} \mathrm{of} \mathrm{the} \mathrm{Nicomachean} \mathrm{Ethics} \mathrm{of} \mathrm{Aristotle.}$ Cambridge: Cambridge University Press.

Kelsen, H. 1937. 'The Philosophy of Aristotle and Hellenic-Macedonian Policy' Ethics 48: 1-64.

Keyt, D. and F.D. Miller, Jr., edd. 1991. A Companion to Aristotle's Politics. Cambridge, MA: Blackwell.

Kraut, R. 2002. Aristotle Political Philosophy. Oxford: Oxford University Press.

Lockwood, T.C. 2006. 'Ethical Justice and Political Justice' Phronesis 50: 29-48.

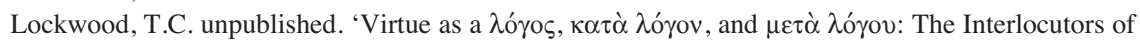
EN VI.13'.

Lord, C. 1978. 'Politics and Philosophy in Aristotle's Politics' Hermes 106: 336-359.

Lord, C. 1982. Education and Culture in the Political Thought of Aristotle. Ithaca, NY: Cornell University Press.

Lord, C. and D.K. O'Connor edd. 1991. Essays on the Foundations of Aristotelian Political Science. Berkeley, CA: University of California Press.

Mansion, S. ed. 1961. Aristote et les problèmes de méthode. Louvain: Publications Universitaires.

Miller, F.D., Jr. 1995. Nature, Justice and Rights in Aristotle's Politics. Oxford: Oxford University Press.

Miller, F.D., Jr. 1996. 'Aristotle and the Origins of Natural Rights' Review of Metaphysics 49: 873907.

Miller, J. 1998. 'Aristotle's Paradox of Monarchy and the Biographical Tradition' History of Political Thought 19: 501-516.

Mulgan, R. 1977. Aristotle's Political Theory. Oxford: Oxford University Press.

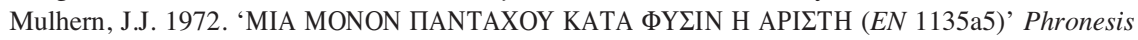
17: 260-268.

Nagle, D.B. 2000. 'Alexander and Aristotle's Pambasileus' L'Antiquité Classique 69: 117-132.

Newell, W.R. 1991. 'Superlative Virtue: The Problem of Monarchy in Aristotle's Politics' 192-211 in Lord and O'Connor edd. 1991.

Newman, W.W. 1887. The Politics of Aristotle. 4 vols. Oxford: Clarendon.

Owens, J. 1978. The Doctrine of Being in the Aristotelian Metaphysics. 3rd edn. Toronto: Pontifical Institute of Mediaeval Studies.

Pakaluk, M. 1998. 'The Egalitarianism of the Eudemian Ethics' Classical Quarterly 48: 411-432.

Pakaluk, M. 1999. Nicomachean Ethics VIII and IX. Oxford: Clarendon.

Piérart, M. ed. 1993. Aristote et Athènes. Fribourg: Séminaire d'histoire ancienne de l'Université de Fribourg.

Rackham, H. 1932. Aristotle's Politics. Loeb Classical Library. Cambridge, MA: Harvard University 
Press.

Ramsauer, G. 1878. Aristotelis Ethica Nicomachea. Leipzig: Tuebener.

Rowe, C.J. 2000. 'Aristotelian Constitutions' 366-389 in Rowe and Schofield edd. 2000.

Rowe, C.J. and M. Schofield edd. 2000. Cambridge History of Greek and Roman Political Thought. Cambridge: Cambridge University Press.

Ross, W.D. 1957. Aristotelis Politica. Oxford: Clarendon.

Rubin, L. ed. 1997. Justice v. Law in Greek Political Thought. Lanham, MD: Rowan and Littlefield Publishers.

Simpson, P. 1998. A Philosophical Commentary on the Politics of Aristotle. Chapel Hill, NC: University of North Carolina Press.

Stewart, J.A. 1892. Notes on the Nicomachean Ethics of Aristotle. 2 vols. Oxford: Clarendon.

Tessitore, A. 1996. Reading Aristotle's Ethics: Virtue, Rhetoric and Political Philosophy. Albany, NY: State University of New York Press.

Vander Waerdt, P.A. 1985a. 'The Political Intention of Aristotle's Moral Philosophy' Ancient Philosophy 5: 77-89.

Vander Waerdt, P.A. 1985b. 'Kingship and Philosophy in Aristotle's Best Regime' Phronesis 30: 249-273.

Vander Waerdt, P.A. 1991. 'The Plan and Intention of Aristotle's Ethical and Political Writings' Illinois Classical Studies 16: 231-253. 